Kozlova O, Wang Way. Improving technical prowess of skilled athletes specialized in long jumps. Theory and Methods of Physical education and sports. 2020; 1: 9-14

DOI: $10.32652 /$ tmfvs.2020.1.9-14
Козлова О, Ван Вей. Удосконалення технічної майстерності кваліфікованих спортсменів, які спеціалізуються у стрибку у довжину. Теорія і методика фрізичного виховання і спорту. 2020; 1: 9-14 DOl: 10.32652/tmfvs.2020.1.9-14

\title{
УДОСКОНАЛЕННЯ ТЕХНІЧНОЇ МАЙСТЕРНОСТІ КВАЛІФІКОВАНИХ СПОРТСМЕНІВ, ЯКІ СПЕЦІАЛІЗУЮТЬСЯ У СТРИБКУ У ДОВЖИНУ
}

\section{Олена Козлова, Ван Вей}

Національний університет фізичного виховання і спорту України, Київ, Україна

\begin{abstract}
Анотація. Стаття присвячена науково-практичному обґрунтуванню напрямів удосконалення технічної майстерності кваліфікованих спортсменів, які спеціалізуються у стрибку у довжину. Мета. Обґрунтувати напрями удосконалення технічної майстерності кваліфікованих спортсменів, які спеціалізуються у стрибку у довжину. Mетоди. Аналіз і узагальнення науково-методичної літератури та мережі Інтернет, відеозйомка; біомеханічний відеокомп'ютерний аналіз; методи математичної статистики. Результати. Визначено інформативні характеристики техніки, від яких залежить досягнення високих спортивних результатів: швидкість розбігу перед відштовхуванням від опори; енергія кінетична в момент постановки ноги на опору у відштовхуванні; швидкість вильоту загального центру маси (ЗЦМ) тіла в момент відриву від опори; енергія повна в момент постановки ноги на опору у відштовхуванні; тривалість фрази відштовхування від опори; енергія кінетична в момент відриву ноги від опори; енергія повна в момент відриву ноги від опори; максимальна висота ЗЦМ тіла в польоті; висота ЗЦМ тіла в момент постановки ноги на опору у відштовхуванні; кут вильоту ЗЦМ тіла; довжина третього кроку перед відштовхуванням; потужність відштовхування. Удосконалення технічної майстерності має знаходитись у тісному взаємозв'язку з розвитком рухових якостей, психічних здібностей стрибунів у довжину з урахуванням типу переважної сенсорної системи. Виділено напрями удосконалення технічної майстерності кваліфікованих спортсменів, які спеціалізуються у стрибку у довжину: орієнтація на інсрормативні характеристики техніки, від яких залежить досягнення високих спортивних результатів у тісному взаємозв'язку з розвитком рухових якостей, психічних здібностей спортсменів з урахуванням типу їхньої переважної сенсорної системи.

Ключові слова: стрибок у довжину, технічна майстерність, рухові якості.
\end{abstract}

\section{Olena Kozlova, Wang Way \\ IMPROVING TECHNICAL PROWESS OF SKILLED ATHLETES SPECIALIZED IN LONG JUMPS}

\begin{abstract}
The article is devoted to scientific and practical substantiation of the directions of improving technical prowess of skilled athletes specialized in long jumps. Objective. Substantiation of the directions for improving technical prowess of skilled athletes specialized in long jumps. Methods. Analysis and generalization of scientific and methodological literature and the Internet, video recording; biomechanical video computer analysis; methods of mathematical statistics. Results. Informative techniques characteristicson on which achievement of high sports results depends are defined: run-up speed before taking-off of the support; kinetic energy at the time of placing the foot on the support in taking-off; speed of departure of the general center of mass (GCM) of the body at the time of leaving the support; total energy at the time of placing the foot on the support in taking-off; duration of taking-off phase; kinetic energy at the moment of leaving the support; total energy at the moment of leaving the support; maximum height of the body GCM in flight; the height of the body GCM at the time of placing the foot on the support in taking-off; departure angle body GCM; length of the third stride before taking-off; taking-off power. The improvement of technical skills should be closely related to the development of motor skills, mental abilities of long jumpers, taking into account the type of the predominant sensory system. Areas of improving the technical prowess of skilled athletes who specialize in long jump have been determined: focus on informative technique characteristics determining the achievement of high sports results in close connection with the development of motor skills, mental abilities of athletes, taking into account the type of their predominant sensory system.
\end{abstract}

Keywords: long jump, technical prowess, motor qualities.

Вступ. Під технічною майстерністю розуміють мистецтво виконання спортсменом системи рухів, що відповідає специфічним особливостям конкретного виду спорту і спрямована на реалізацію рухових можливостей, що забезпечує досягнення високих спортивних результатів [8, 9]. Проблема удо- сконалення технічної майстерності давно привертала увагу вчених, що було відображено в спеціальній літературі [1, 6, 13, 17]. Увагу фахівців у галузі спорту було зосереджено на аналізі біомеханічних показників техніки спортсменів високої кваліфікації, які спеціалізуються у легкоатлетич- 
них стрибках [2, 7, 12], на використанні засобів технічної підготовки, моделюванні змагальної діяльності [5], індивідуальних кінематичних і енергетичних показників техніки в стрибку у довжину [14, 16].

Не дивлячись на велику кількість різноманітного матеріалу з цієї наукової проблеми, необхідність проведення подальших досліджень пов'язана з уточненням інформативних показників техніки у стрибку у довжину з урахуванням не тільки специфіки змагальної діяльності, а й кваліфікації спортсменів. Зазвичай більшість досліджень, присвячених удосконаленню технічної майстерності, було проведено зі спортсменами високої кваліфікації, які спеціалізуються у стрибку у довжину. Також бракує наукових даних, котрі розкривають роль фізичної і психологічної підготовки для удосконалення технічної майстерності з урахуванням специфіки виду спорту і кваліфікації спортсменів. Все це потребує проведення подальших досліджень, визначення напрямів удосконалення технічної майстерності кваліфікованих спортсменів 3 урахуванням специфіки виду змагань - стрибків у довжину .

Дослідження виконано відповідно до Зведеного плану науково-дослідної роботи у сфері фізичної культури і спорту на 2016-2020 pp. Національного університету фізичного виховання i спорту України за темою 2.27. «Удосконалення системи спортивної підготовки і змагальної діяльності кваліфікованих спортсменів у сучасних умовах інтенсифікації змагальної діяльності» (номер держреєстрації 0174000806).

Мета дослідження - обгрунтувати напрями удосконалення технічної майстерності кваліфікованих спортсменів, які спеціалізуються у стрибку у довжину.

Методи дослідження: аналіз і узагальнення науково-методичної літератури та мережі Інтернет; відеозйомка; біомеханічний відеокомп'ютерний аналіз; методи математичної статистики.

Результати дослідження та їх обговорення. Технологія проведення біомеханічного відеокомп'ютерного аналізу включала два основних етапи:

- відеозйомка двома відеокамерами GoPro Hero4 з частотою 120 кадр $\cdot \mathrm{c}^{-1} 3$ дотриманням метрологічних вимог;

- обробка отриманих відеограм за допомогою спеціалізованого програмного забезпечення «DARTFISH» (Швейцарія), Motion Analysis Tools i «БіоВідео». Програмне забезпечення «БіоВідео» було розроблене на кафедрі біомеханіки Національного університету фізичного виховання і спорту України I. В. Хмельницькою [11].

Відеозйомку техніки стрибків у довжину здійснювали на чемпіонаті м. Києва. У дослідженні взяли участь 14 кваліфікованих спортсменів 1723 років. Від усіх учасників було отримано інформовану згоду на участь у дослідженнях. Процедури проводили відповідно до етичних стандартів відповідального комітету з прав експериментів або декларації Гельсінкі 2008 р. Результати, показані спортсменами у змаганнях, відповідали нормативу кандидата в майстри спорту, I та II розрядам у стрибку у довжину. Аналізували 40 вдалих спроб, середній спортивний результат $-6,21$ м. За допомогою науково-методичної літератури було встановлено 20 біомеханічних показників техніки, від яких залежить спортивний результат у стрибку у довжину. На основі використання кореляційного аналізу встановлювали інформативні показники техніки виконання змагальної вправи.

Математичну обробку результатів досліджень виконували з використанням програмного забезпечення IBM SPSS Statistics.

Стрибок у довжину відносять до складнокоординаційних швидкісно-силових видів легкої атлетики, який складається 3 таких частин: розбіг; відштовхування; політ; приземлення, де спортивний результат значною мірою залежить від багатьох чинників: раціональної техніки виконання рухів, розвитку рухових і психічних якостей (рис. 1).

Технічна підготовка виступає як засіб реалізації фізичних можливостей спортсмена. У результаті проведення кореляційного аналізу було визначено інформативні показники техніки, що впливають на досягнення високих спортивних результатів у стрибку у довжину (див. рис. 1). Встановлено високий кореляційний зв'язок швидкості розбігу $(\mathrm{r}=0,91, \mathrm{p}<0,05)$, енергії кінетичної в момент постановки ноги на опору у відштовхуванні $(\mathrm{r}=0,78, \mathrm{p}<0,05)$, швидкість вильоту ЗЦМ тіла в момент відриву від опори $(\mathrm{r}=0,76, \mathrm{p}<0,05)$, тривалості фази відштовхування від опори ( $\mathrm{r}=-0,71$, $\mathrm{p}<0,05)$, енергії повної в момент постановки ноги на опору у відштовхуванні $(\mathrm{r}=-0,74, \mathrm{p}<0,05)$ зі спортивним результатом при встановленому критерії значущості $(r=0,35)$, а також іншими показниками, наведеними у таблиці 1.

Фізична підготовка є формуючою основою рухової діяльності [6]. Спортивний результат у стрибку у довжину залежить від розвитку рухових якостей. Головним завданням є виявлення тих рухових якостей, які значною мірою визначають результат у даному виді легкої атлетики [3], де домінують основні п’ять (див. рис. 1).

Сила як рухова якість є важливою для спортсменів, які спеціалізуються у стрибку у довжину. Особливо важливо удосконалювати потужність (максимальний прояв силових якостей і швидкості під час розбігу і відштовхування), яка є основою успіху у стрибках у довжину. Для підвищення потужності найчастіше використовують засоби балістичного і пліометричного характеру. Під час розвитку сили необхідно звертати особливу увагу на зміцнення зв'язок і сухожилок, які оточують колінний, надп'ятково-гомілковий і кульшовий суглоби [15]. Сила певних м'язових груп (поперечні м'язи живота; клубово-поперекові м'язи; м'язи тазового дна; квадратні м'язи попереку; багатороз- 


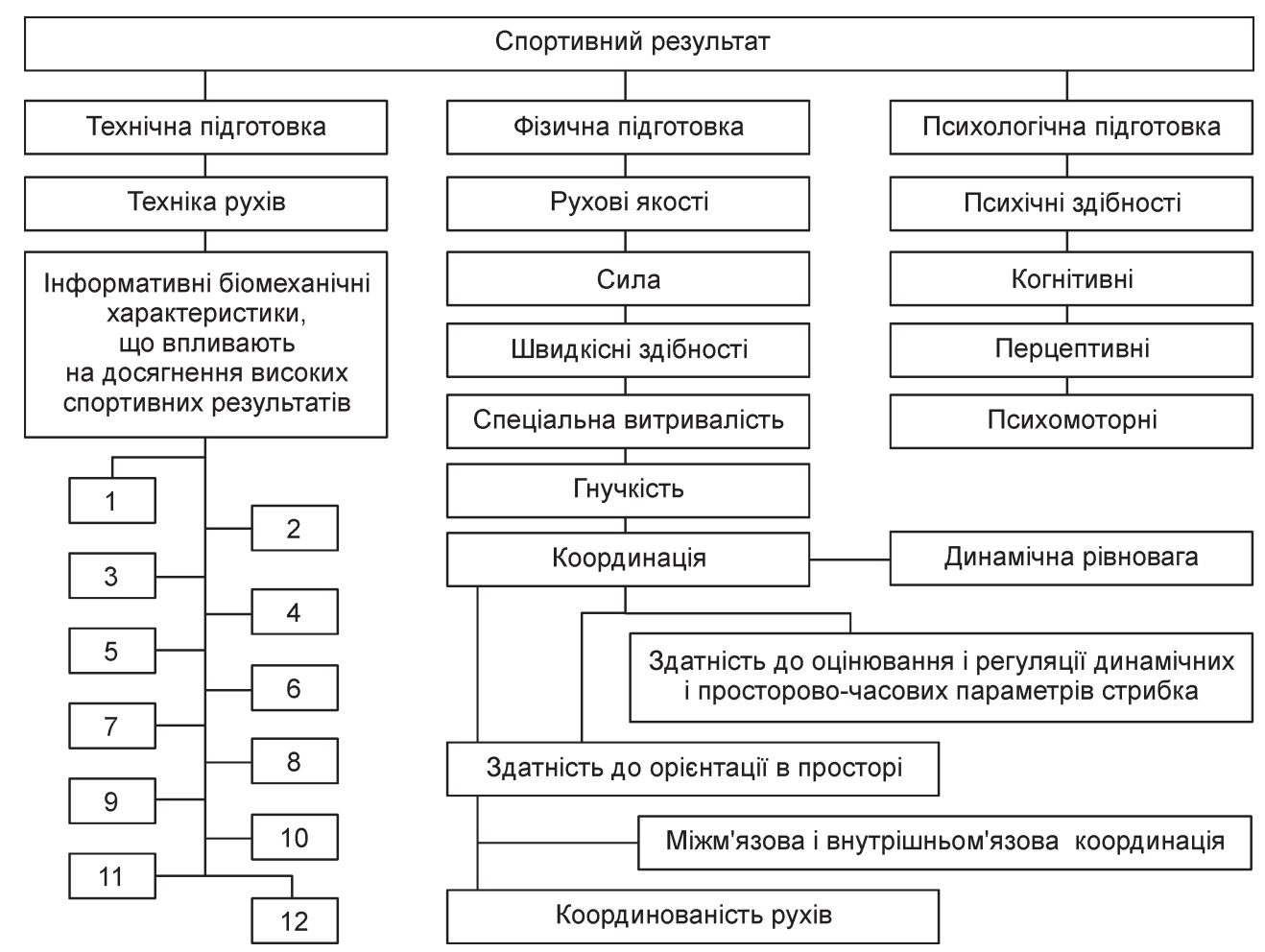

Рисунок 1 - Компоненти структури удосконалення технічної майстерності спортсменів, які спеціалізуються в стрибку у довжину:

1 - швидкість розбігу перед відштовхуванням від опори, м · $\mathrm{c}^{-1} ; 2$ - енергія кінетична в момент постановки ноги на опору у відштовхуванні, Дж; 3 - швидкість вильоту ЗЦМ тіла в момент відриву від опори, м · $\mathrm{c}^{-1} ; 4$ - енергія повна в момент постановки ноги на опору у відштовхуванні, Дж; 5 - тривалість фрази відштовхування від опори, с; 6 - енергія кінетична в момент відриву ноги від опори, Дж; 7 - енергія повна в момент відриву ноги від опори, Дж; 8 - максимальна висота ЗЦМ тіла в польоті; 9 - висота ЗЦМ тіла в момент постановки ноги на опору у відштовхуванні, м; 10 - кут вильоту ЗЦМ тіла, град.; 11 - довжина третього кроку перед відштовхуванням, м; 12 - потужність відштовхування, Вт

дільні м’язи), які формують поставу, забезпечують стабільність попереково-кульшового комплексу [8], сприяють стабілізації нижньої частини хребта, таза і стегна, є дуже істотною у стрибку у довжину. Наслідки недостатньої силової підготовки цих м'язових груп - порушення координації рухів, стійкості і рівноваги, нераціональна техніка виконання рухових дій, зайве напруження під час виконання рухових дій та неефективне їх виконання, травматизм. Для спортсменів, які спеціалізуються у стрибку у довжину, важливо удосконалювати динамічну рівновагу, здатність до оцінювання і регуляції динамічних і просторовочасових параметрів стрибка, орієнтації в просторі, міжм'язову і внутрішньом' язову координацію, координованість рухів.

Розвиток рухових якостей повинен знаходитися в тісному взаємозв'язку з технікою стрибка у довжину з орієнтацією на інформативні біомеханічні характеристики техніки, що впливають на досягнення високих спортивних результатів. Дуже важливо, щоб розвиток рухових якостей не входив у протиріччя з удосконаленням техніки змагальної вправи, що досягається підбором спеціальних вправ.

Психологічна підготовка як основа управління руховими діями тісно пов'язана зі здібностями спортсменів. До загальних здібностей відносять: когнітивні (пізнавальні), перцептивні (пов'язані 3 сприйняттям ситуації), психомоторні (пов’язані 3 виконанням рухових дій) [10]. Проте високий рівень перерахованих загальних здібностей не виключає особливих вимог до удосконалення спеціальних здібностей, тобто тих, які тісно пов'язані зі специфікою виду спорту, виду змагань. Для стрибунів у довжину важливим є оцінювання простору, часу, точного попадання на брусок для відштовхування, а також м'язових зусиль.

Тип сенсорної системи спортсменів впливає на особливості сприйняття, а отже під час навчання й удосконалення рухових дій може впливати на якість їхньої технічної підготовки. Перші думки про особливості сприйняття зустрічаються в працях філософів античності. Приблизно в VI ст. до н. е. мислителі почали помічати різницю в сприйнятті своїх учнів і описувати свої спостереження. Існують різні типи сприйняття навколишньої дійсності: аудіальний (орієнтований на сприйняття інформації на слух), візуальний (превалює зір), кінестетичний (орієнтація на тактильні відчуття), дигітальний (дискретний) (превалює логіка). Необхідно сказати, що чисті типи зустрічаються вкрай рідко, йдеться про схильність. 
Таблиця 1 - Коефіцієнти кореляції показників рухових дій стрибунів у довжину зі спортивним результатом

\begin{tabular}{|c|c|c|}
\hline № $3 / n$ & Показник & $\begin{array}{l}\text { Спортивний } \\
\text { результат, м }\end{array}$ \\
\hline 1 & Маса тіла & $-0,13$ \\
\hline 2 & Довжина тіла & $-0,05$ \\
\hline 3 & $\begin{array}{l}\text { Мінімальний кут у колінному сугло- } \\
\text { бі опорної ноги у фазі відштовхуван- } \\
\text { ня, град. }\end{array}$ & 0,16 \\
\hline 4 & $\begin{array}{l}\text { Кут розгинання кульшового сугло- } \\
\text { ба опорної ноги в момент відриву від } \\
\text { опори, град. }\end{array}$ & 0,26 \\
\hline 5 & $\begin{array}{l}\text { Тривалість фази відштовхування від } \\
\text { опори, с }\end{array}$ & $-0,71^{\star}$ \\
\hline 6 & $\begin{array}{l}\text { Швидкість розбігу перед відштовху- } \\
\text { ванням від опори, } \text { м }^{-1} \mathrm{c}^{-1}\end{array}$ & $0,91^{*}$ \\
\hline 7 & Кут вильоту ЗЦМ тіла, град. & $0,47^{*}$ \\
\hline 8 & $\begin{array}{l}\text { Швидкість вильоту ЗЦМ тіла в мо- } \\
\text { мент відриву від опори, м · } \mathrm{c}^{-1}\end{array}$ & $0,76^{*}$ \\
\hline 9 & $\begin{array}{l}\text { Висота ЗЦМ тіла в момент постанов- } \\
\text { ки ноги на опору у відштовхуванні, м }\end{array}$ & $0,49^{\star}$ \\
\hline 10 & $\begin{array}{l}\text { Висота ЗЦМ тіла в момент відштов- } \\
\text { хування, м }\end{array}$ & 0,30 \\
\hline 11 & $\begin{array}{l}\text { Висота ЗЦМ тіла в момент відриву } \\
\text { ноги від опори у відштовхуванні, м }\end{array}$ & 0,18 \\
\hline 12 & $\begin{array}{l}\text { Висота ЗЦМ тіла у найвищій точці у } \\
\text { польоті, м }\end{array}$ & $0,55^{\star}$ \\
\hline 13 & Довжина останнього кроку, м & 0,13 \\
\hline 14 & $\begin{array}{l}\text { Довжина передостаннього кроку пе- } \\
\text { ред відштовхуванням, м }\end{array}$ & 0,02 \\
\hline 15 & $\begin{array}{l}\text { Довжина третього кроку перед від- } \\
\text { штовхуванням, м }\end{array}$ & $0,41^{*}$ \\
\hline 16 & $\begin{array}{l}\text { Енергія потенційна в момент поста- } \\
\text { новки ноги на опору у відштовхуван- } \\
\text { ні, Дж }\end{array}$ & 0,07 \\
\hline 17 & $\begin{array}{l}\text { Енергія потенційна в момент відриву } \\
\text { від опори, Дж }\end{array}$ & $-0,23$ \\
\hline 18 & $\begin{array}{l}\text { Енергія кінетична в момент поста- } \\
\text { новки ноги на опору у відштовхуван- } \\
\text { ні, Дж }\end{array}$ & $0,78^{*}$ \\
\hline 19 & $\begin{array}{l}\text { Енергія кінетична в момент відриву } \\
\text { від опори, Дж }\end{array}$ & $0,64^{*}$ \\
\hline 20 & $\begin{array}{l}\text { Енергія повна в момент постановки } \\
\text { ноги на опору у відштовхуванні, Дж }\end{array}$ & $0,74^{\star}$ \\
\hline 21 & $\begin{array}{l}\text { Енергія повна в момент відриву від } \\
\text { опори, Дж }\end{array}$ & $0,63^{*}$ \\
\hline 22 & Потужність в фазі відштовхування, Вт & $0,35^{\star}$ \\
\hline
\end{tabular}

Примітка. * Коефіцієнти кореляції статистично значущі на рівні $\mathrm{p}<0,05$

Можна припустити, що визначення переважного сенсорного типу у конкретного спортсмена дозволить цілеспрямовано впливати на його сильні сторони і тим самим підвищити ефективність управління рухами у процесі технічного удосконалення.

Серед спортсменів, які спеціалізуються у швидкісно-силових видах легкої атлетики, провід- ними типами сенсорної системи в однаковій мірі $€$ аудіальний i кінестетичний [4]. Проте експериментальних досліджень у цьому напрямі проведено недостатньо через специфіку виду змагань (стрибок у довжину), що потребує подальшого вивчення. Особливо це стосується підбору тренувальних впливів у процесі технічного удосконалення з орієнтацією на тип сенсорної системи. Можна припустити, що для стрибунів-аудіалів процес удосконалення технічної майстерності буде найбільш ефективним, коли тренер буде частіше використовувати словесний метод, тобто здійснювати зворотний зв'язок за допомогою слова, інтонації, озвучувати настанови до виконання спеціальних вправ, окремих елементів та стрибка у довжину в цілому. Прослуховування аудіозаписів iз заплющеними очима, повторювання неголосно настанов тренера, використання різних звукових орієнтирів для опанування темпо-ритмової структури розбігу, звуколідера (приладу, що дозволяє спортсменові контролювати час виконання вправи, орієнтуючись на звуки, що подаються через заданий інтервал), музичний супровід також можуть бути корисним для спортсменів, у яких переважає сприйняття інформації на слух.

Візуалам у процесі технічного удосконалення слід орієнтуватися переважно на зорові орієнтири під час виконання вправ (наприклад, під час відштовхування спрямувати погляд на певний предмет, розставити орієнтири на доріжці для удосконалення темпо-ритмової структури розбігу, точності попадання на брусок тощо), переглядати відеофільми, спостерігати за технікою спортсменів високої кваліфікації, здійснювати контроль за технікою на основі запису спроб стрибків у довжину або інших вправ на відео, а після їх виконання переглядати відео, рисувати схеми стрибка тощо.

Кінестетикам удосконалення рухів переважно слід спрямувати на відчуття власного тіла, взаємодії з опорою під час відштовхування, часу, простору (наприклад, виконання стрибка у довжину 3 різних розбігів, на жорсткій, м'якій доріжці, виконання спеціальних вправ зі зміною темпу, з заплющеними очима тощо).

Для дигіталів, які сприймають навколишній світ за допомогою логіки, треба обгрунтовувати причинно-наслідкові зв'язки під час удосконалення техніки рухових дій, переваги і недоліки використання певних засобів.

Технічне удосконалення стрибунів у довжину повинне відбуватися у єдності з розвитком їхніх психічних здібностей $з$ орієнтацією на тип переважної сенсорної системи.

Дискусія. Процес формування технічної майстерності необхідно поєднувати, перш за все, зі специфікою змагальної діяльності і кваліфікацією спортсменів, що здійснюється на основі виявлених передумов, які обумовлюють досягнення високих спортивних результатів: раціональної організації змагальної вправи, рівня фізичної і психічної підготовленості. Формування перерахованих компо- 
нентів (передумов), від яких залежить технічна майстерність, відбувається на основі виявлених об'єктивних критеріїв і закономірностей. У процесі дослідження визначено інформативні біомеханічні показники техніки, які є об'єктивними критеріями для удосконалення технічної майстерності кваліфікованих стрибунів у довжину. Отримані наукові дані розширюють існуючі, які стосуються аналізу техніки спортсменів у стрибку у довжину [7]. Підтверджено важливість горизонтальної швидкості ЗЦМ тіла в момент відштовхування. Відзначено високий ступінь кореляції між швидкістю розбігу та спортивним результатом. Наші дані цього коефіцієнта становлять $\mathrm{r}=0,91$, вони вищі, ніж в інших дослідженнях [1, 2, 7]. Нами встановлено високий взаємозв'язок енергетичних характеристик техніки зі спортивним результатом: енергія кінетична в момент постановки ноги на опору у відштовхуванні $\mathrm{r}=0,78$; енергія кінетична в момент відриву від опори $\mathrm{r}=-0,64$; енергія повна в момент постановки ноги на опору у відштовхуванні $\mathrm{r}=-0,74$; енергія повна в момент відриву від опори $r=0,63$. У процесі формування технічної майстерності легкоатлетів-стрибунів високої кваліфікації вирішуються такі завдання:

- формування раціональної техніки виконання легкоатлетичних змагальних стрибків спортсменами високої кваліфікації;

- забезпечення необхідного рівня розвитку силових, швидкісних і координаційних здібностей спортсменів;

- забезпечення необхідного рівня психічних здібностей стрибунів у довжину як основи для управління руховими діями.

Удосконалення технічної майстерності може відбуватись на основі урахування типу сенсорної системи спортсменів [4]. Раніше було визначено тип сенсорної системи легкоатлетів різних спеціалізацій, проте, як було зазначено раніше, експериментальних досліджень у цьому напрямі проведено недостатньо через специфіку виду змагань (стрибок у довжину), що потребує проведення додаткових досліджень. Проведені дослідження відкривають нові можливості для інтеграції знань в єдину систему, доповнення і уточнення різних складових для удосконалення технічної майстерності.

Висновки. Процес формування технічної майстерності необхідно пов'язувати, перш за все, зі специфікою змагальної діяльності і кваліфікацією спортсменів, що здійснюється на основі виявлених передумов, які обумовлюють досягнення високих спортивних результатів

Визначено напрями удосконалення технічної майстерності:

- формування техніки змагальної вправи з орієнтацією на інформативні біомеханічні показники, від яких залежить досягнення високих спортивних результатів у стрибку у довжину: швидкість розбігу перед відштовхуванням від опори; енергія кінетична в момент постановки ноги на опору у відштовхуванні; швидкість вильоту ЗЦМ тіла в момент відриву від опори; енергія повна в момент постановки ноги на опору у відштовхуванні; тривалість фази відштовхування від опори; енергія кінетична в момент відриву ноги від опори; енергія повна в момент відриву ноги від опори; максимальна висота ЗЦМ тіла в польоті; висота ЗЦМ тіла в момент постановки ноги на опору у відштовхуванні; кут вильоту ЗЦМ тіла; довжина третього кроку перед відштовхуванням; потужність відштовхування;

- забезпечення необхідного рівня розвитку силових, швидкісних і координаційних здібностей спортсменів у тісному взаємозв'язку з раціональною технікою стрибка у довжину;

- забезпечення необхідного рівня психічних здібностей кваліфікованих стрибунів у довжину як основи для управління руховими діями у процесі технічного удосконалення 3 орієнтацією на тип переважної сенсорної системи спортсмена.

Конфлікт інтересів. Автори заявляють, що відсутній будь-який конфлікт інтересів.

\section{Література}

1. Бобровник ВИ. Козлова ЕК. Совершенствование технического мастерства легкоатлетов-прыгунов высокой квалификации. Мир спорта. 2008; 1:31-4.

2. Бобровник ВИ, Козлова ЕК. Легкоатлетические прыжки в кн. Легкая атлетика [Аурутин СЮ, Артюшенко АФ, Беца НН и др.]. Киев: Логос. 2017. с. 405-552.

3. Брукс К. Классификация двигательных качеств. Легкоатлетический вестник ИААФ. 2013;3-4:135-142.

4. Высочина НЛ, Козлова ЕК. Особенности проявления психических свойств личности у квалифицированных легкоатлетов в условиях стресса. Науковий часопис. Науково-педагогічні проблеми фрізичної культури. Фізична культура і спорт 2014;9 (50):33-6.

5. Добрынская Н, Козлова Е. Моделирование соревновательной деятельности как основа индивидуализации построения многолетней подготовки в легкоатлетическом многоборье (женщины). Наука в олимпийском спорте. 2013; 3:13-20.

6. Дьячков ВМ. Совершенствование технического мастерства спортсменов (Педагогические проблемы управления). Москва: Физкультура и спорт; 1972. 230 с.

7. Мендоса Л, Никсдорф Э. Биомеханический анализ горизонтальных прыжков на чемпионате мира по легкой атлетике ИААФ 2009 года. Легкоатлетический вестник ИААФ. 2011;3-4:25-60.

8. Платонов ВН. Система подготовки спортсменов в олимпийском спорте. Общая теория и ее практические приложения: учебник для тренеров. Киев: Олимпийская лит.; 2015. Кн. 2. 752 с. 
9. Платонов ВН. Двигательные качества и физическая подготовка спортсменов. Киев: Олимпийская лит.; 2017. 659 c.

10. Туманян ГС. Стратегия подготовки чемпионов: настольная книга тренера. Москва: Сов. спорт; 2006. $496 \mathrm{c}$.

11. Хмельницька IB. Програмний комплекс біомеханічного відеокомп'ютерного аналізу рухів людини. Теорія і методика фрізичного виховання і спорту. 2004; 2:150-156.

12. Энкарнатион A, Гултирес-Давила М, Раяс Д. 3D кинематический анализ прыжков в длину на чемпионате мира в помещении 2008 года. Легкоатлетический вестник ИААФ. 2013;3-4:115-134. 7-9.

13. Hilliard C. Technical preparation \& coaching drills for the long jump. Modern Athlete and Coach. 2007; 45(3):

14. Kozlova E, Wang Wei, Kozlov K. Individual peculiarities of long jump technique of skilled athletes. Journal of Physical Education and Sport. 2020;20:408-412, ISSN: 2247- 806X; p-ISSN: 2247- 8051; ISSN - L = 2247- 8051 c JPES.

15. Shiffer Y. Horizontal jumps. IAAF New Studies in Athletics. 2011;3-4:7-22.

16. Wang Wei, Kozlova E. Research on the training content system of long jumpers. Sports World (Scholarly). 2019;3:10-11.

17. Wensor D. Teach kids long jump in 30 minutes. Modern Athlete and Coach, 2010;48(3): 8-10.

\section{Literature}

1. Bobrovnik VI. Kozlova E.K. Improving technical prowess of highly skilled track and field jumpers. Mir sporta. 2008; 1:31-4.

2. Bobrovnik VI. Kozlova E.K. Track and field jumps. In: Track and field Aurutin SY, Artyushchenko AF, Betsa NN et al. Kiev: Logos. 2017. p. 405-552.

3. Bruks K. Classification of motor qualities. Legkoatleticheskiy vestnik IAAF. 2013;3-4:135-142.

4. Vysochina NL, Kozlova EK. Peculiarities of manifesting mental personality features in skilled track and field athletes under stress comditions. Naukovyi chasopys. Fizychna kultura i sport 2014;9 (50):33-6.

5. Dobrynskaya N, Kozlova E. Modeling competitive activity as a basis for individualization of long-term preparation design in track and field all around (women). Nauka v Olimpiyskom sporte. 2013; 3:13-20.

6. Dyachkov VM. Improving athletes' technical skills (Pedagogical problems of management). Moscow: Fizkultura i sport; 1972. 230 p.

7. Mendosa L, Niksdorf E. Biomechanical analysis of horizontal jumps at the IAAF 2009 World Championship. Legkoatleticheskiy vestnik IAAF. 2011;3-4:25-60.

8. Platonov VN. System of athletes' preparation in the Olympic sport. General theory and its practical applications: textbook: Kiev: Olimpiyskaya literatura; 2015. B. 2. 752 p.

9. Platonov VN. Motor qualities and physical training of athletes. Kiev: Olimpiyskaya literatura; 2017. 659 p.

10. Tumanyan GS. Strategy of champions preparation: coach bible. Moscow: Sov. sport; 2006. 496 p.

11. Khmelnytska IV. Program complex of biomechanical video computer analysis of human motions. Teoriia i metodyka fizvykhovannia i sportu. 2004; 2:150-156.

12. Enkarnation A, Gultires-Davila M, Rayas D. 3D kinematic analysis of long jumps at 2008 World Championship. Legkoatleticheskiy vestnik IAAF. 2013;3-4:115-134. 7-9.

13. Hilliard C. Technical preparation \& coaching drills for the long jump. Modern Athlete and Coach. 2007; 45(3):

14. Kozlova E, Wang Wei, Kozlov K. Individual peculiarities of long jump technique of skilled athletes. Journal of Physical Education and Sport. 2020;20:408-412, ISSN: 2247- 806X; p-ISSN: 2247- 8051; ISSN - L = $2247-8051$ c JPES.

15. Shiffer Y. Horizontal jumps. IAAF New Studies in Athletics. 2011;3-4:7-22.

16. Wang Wei, Kozlova E. Research on the training content system of long jumpers. Sports World (Scholarly). 2019;3:10-11.

17. Wensor D. Teach kids long jump in 30 minutes. Modern Athlete and Coach, 2010;48(3): 8-10.

Надійшла 21.02.2020

\section{Інформація про авторів}

Козлова Олена Костянтинівна https://orcid.org/0000-0003-2179-3970 naukasport777@gmail.com

Національний університет фізичного виховання і спорту України, вул. Фізкультури 1, м. Київ, 03150, Україна

\section{Information about the authors}

Kozlova Olena

https://orcid.org/0000-0003-2179-3970

naukasport777@gmail.com

Національний університет

фізичного виховання і спорту України,

вул. Фізкультури 1, м. Київ, 03150, Україна 